\title{
Prevalence of Obesity Among U.S. Workers and Associations with Occupational Factors
}

\author{
Sara E. Luckhaupt, MD, MPH, Martha A. Cohen, PhD, Jia Li, MS, Geoffrey M. Calvert, MD, MPH \\ This activity is available for CME credit. See page A4 for information.
}

\begin{abstract}
Background: Along with public health and clinical professionals, employers are taking note of rising obesity rates among their employees, as obesity is strongly related to chronic health problems and concomitant increased healthcare costs. Contributors to the obesity epidemic are complex and numerous, and may include several work characteristics.
\end{abstract}

Purpose: To explore associations between occupational factors and obesity among U.S. workers.

Methods: Data from the 2010 National Health Interview Survey were utilized to calculate weighted prevalence rates and prevalence ratios (PRs) for obesity in relation to workweek length, work schedule, work arrangement, hostile work environment, job insecurity, work-family imbalance, and industry and occupation of employment. Data were collected in 2010 and analyzed in 2012-2013.

Results: Overall, $27.7 \%$ of U.S. workers met the BMI criterion for obesity. Among all workers, employment for more than 40 hours per week and exposure to a hostile work environment were significantly associated with an increased prevalence of obesity, although the differences were modest. Employment in health care and social assistance and public administration industries, as well as architecture and engineering, community and social service, protective service, and office and administrative support occupations was also associated with increased obesity prevalence.

Conclusions: Work-related factors may contribute to the high prevalence of obesity in the U.S. working population. Public health professionals and employers should consider workplace interventions that target organization-level factors, such as scheduling and prevention of workplace hostility, along with individual-level factors such as diet and exercise.

(Am J Prev Med 2014;46(3):237-248) Published by Elsevier Inc. on behalf of American Journal of Preventive Medicine

\section{Introduction}

7 he CDC recognizes obesity as a national epidemic. ${ }^{1,2}$ At the same time, the CDC has identified obesity, along with nutrition and physical activity, as a "winnable battle" because measurable progress can be quickly made by developing policy, systems, and environmental initiatives that help make healthy choices available, affordable, and easy (http://www.cdc.gov/WinnableBattles/ Obesity/index.html). Along with public health and clinical professionals, employers are taking note of rising obesity rates among their employees, as obesity is

From the Division of Surveillance, Hazard Evaluations and Field Studies, National Institute for Occupational Safety and Health, CDC, Cincinnati, Ohio

Address correspondence to: Sara E. Luckhaupt, MD, MPH, National Institute for Occupational Safety and Health, 4676 Columbia Parkway, R-17, Cincinnati OH 45226. E-mail: sluckhaupt@cdc.gov.

0749-3797/\$36.00

http://dx.doi.org/10.1016/j.amepre.2013.11.002 strongly related to chronic health problems and concomitant increased healthcare costs. ${ }^{3}$

Contributors to the obesity epidemic are complex and numerous, and may include several work characteristics. ${ }^{4-6}$ These range from work organization factors such as long workweeks $^{6,7}$ and shiftwork ${ }^{8-12}$ to psychosocial factors such as job stress. ${ }^{6,13}$ All of these factors may contribute to obesity, at least partially, by influencing health behaviors. For example, total caloric intake and unhealthy eating behaviors are positively associated with stress, ${ }^{14-17}$ and long workweeks may decrease the opportunity for physical activity. ${ }^{18}$ On the other hand, shift work may also increase the risk of obesity through physiologic maladaptation, ${ }^{19}$ and chronic stress from any of these work factors may contribute directly to obesity by promoting deposition of intra-abdominal fat. ${ }^{20}$ These factors may help explain why the prevalence of obesity has been shown to vary considerably across U.S. occupational groups. ${ }^{21}$

Job stress can be defined as the harmful physical and emotional responses that occur when job requirements 
do not match the capabilities, resources, or needs of the worker. ${ }^{22}$ Much of the previous research regarding job stress and obesity has focused on the demand-control model $^{6,23-25}$ or effort-reward imbalance model, ${ }^{6,26-28}$ with mixed results. ${ }^{4,6}$ Specific individual work-related psychosocial stressors recently linked to physiological and psychological stress responses and poor health behaviors include a hostile work environment (i.e., exposure to threats, bullying, or harassment on the job), ${ }^{29,30}$ job insecurity, ${ }^{6,31-33}$ and work-family imbalance $^{34}$; however, associations between these stressors and obesity have not been well described.

In 2010, the National Institute for Occupational Safety and Health (NIOSH) sponsored an Occupational Health Supplement to the National Health Interview Survey (NHIS-OHS) to collect nationally respresentative data on working conditions, potentially hazardous exposures, and work-related health outcomes among U.S. workers. The present study utilized the NHIS-OHS data regarding work organization characteristics (workweek length, work shift, and work arrangement) ${ }^{35}$ and work-related psychosocial stressors (hostile work environment, job insecurity, and work-family imbalance ${ }^{36}$ to investigate whether these factors represent stressful work conditions that may be associated with obesity among a large, nationally representative sample that includes U.S. workers from all industry and occupation (I and $\mathrm{O}$ ) categories. The findings may help explain differences in the prevalence of obesity by I and $\mathrm{O}$.

\section{Methods}

\section{Study Sample}

The National Center for Health Statistics (NCHS) within the CDC has conducted the NHIS, a cross-sectional in-person household survey used to monitor the health of the nation, since $1957 .{ }^{37}$ With the exclusion of individuals in long-term care facilities, correctional facilities, active-duty Armed Forces personnel, and U.S. nationals within foreign countries, the data are considered to be representative of the U.S. population. The survey employs a multistage clustered sample design with oversampling of Blacks, Hispanics, and Asians.

Each year the NHIS includes (1) a core set of questions that change little from year to year and (2) supplemental questions varying from year to year that are concerned with nationally important, timely health issues. Supplements to the 2010 NHIS included sample adult occupational health questions and a sample adult cancer control questionnaire. The data presented in this paper are based on $57.6 \%$ of 27,157 sample adults who were employed during the week preceding their interviews (i.e., current workers). The sample adult response rate was $60.8 \%$.

The Research Ethics Review Board of the NCHS (Protocol \#2009-16) and the U.S. Office of Management and Budget (Control \#0920-0214) both approved the 2010 NHIS. In lieu of written consent, 2010 NHIS respondents provided oral consent before participating.

\section{Measures}

Obesity. The main outcome for this study, obesity, was defined as a BMI of $\geq 30$, based on self-reported weight and height values.

Industry and occupation. Information about sample adults' current industry (employer's type of business) and occupation (employee's type of work) of employment was collected in narrative form. To these data, coding experts assigned four-digit Census I and O codes based on the 2007 North American Industrial Classification System (NAICS) and the 2010 Standard Occupational Classification (SOC) system. These codes were then collapsed into 20 industry groups that approximate NAICS sectors and 22 occupation groups that approximate SOC major groups to allow for more-reliable estimates.

Work organization characteristics. With the exception of work hours, which are collected as part of the core Family Module, data regarding work organization characteristics and work-related psychosocial stressors came from the OHS. Long work hours were defined as having worked more than 40 hours in the past week, and part-time work was defined as working less than 35 hours.

Work-related psychosocial stressors. Hostile work environment was defined as answering "yes" to the question During the past 12 months were you threatened, bullied, or harassed by anyone while you were on the job? Job insecurity and work-family imbalance were measured by asking the participant whether they strongly agreed, agreed, disagreed, or strongly disagreed with a particular statement regarding their current job. No specific time frame was specified. Job insecurity was assessed with the statement "I am worried about becoming unemployed." Responses of "strongly agree" and "agree" were defined as job insecurity. Work-family imbalance was assessed with the statement "It is easy for me to combine work with family responsibilities." Responses of "strongly disagree" and "disagree" were defined as work-family imbalance.

Potential confounders. Because the following demographic variables may be related to obesity and the exposure variables, they were treated as potential confounders: gender, age, race/ethnicity, and education. Race/ethnicity was stratified as non-Hispanic white, non-Hispanic black, non-Hispanic Asian, non-Hispanic other, or Hispanic.

Some models also included the following health behaviors, which have been shown to be associated with obesity and vary by employment characteristics (e.g., I and O): smoking, exercise, and fruit and vegetable consumption. Exercise was dichotomized as meeting vs. not meeting CDC recommendations for aerobic activity for adults (150 minutes of moderate-intensity aerobic activity or 75 minutes of vigorous-intensity aerobic activity per week or some combination of the two; http://www.cdc.gov/ physicalactivity/everyone/guidelines/adults.html), based on the reported frequency of leisure-time light/moderate and vigorous activity per week multiplied by the duration of each level of exercise. Daily fruit and vegetable consumption was used as a surrogate for healthy eating behavior, based on the Dietary Guidelines for Americans recommendation that eating more of these foods instead of higher-calorie foods can help adults and 
Table 1. Prevalence of obesity and mean BMI among U.S. workers by demographic characteristics and health behaviors, 2010

\begin{tabular}{|c|c|c|c|c|c|c|}
\hline Characteristic & $\begin{array}{l}\text { Unweighted } \\
\text { sample size }\end{array}$ & $\begin{array}{l}\text { Estimated population } \\
\quad \text { (in millions) }\end{array}$ & $\begin{array}{l}\text { Weighted mean BMI } \\
\qquad(95 \% \mathrm{Cl})\end{array}$ & $\begin{array}{l}\text { Unweighted obesity } \\
\text { cases }\end{array}$ & $\begin{array}{c}\text { Weighted prevalence } \\
(\%, \text { SE) }\end{array}$ & $\begin{array}{c}\mathrm{PR} \\
(95 \% \mathrm{Cl})\end{array}$ \\
\hline \multicolumn{7}{|c|}{ BY DEMOGRAPHIC CHARACTERISTICS } \\
\hline \multicolumn{7}{|l|}{ Gender } \\
\hline Male & 7,529 & 72.2 & $28.0(27.8,28.1)$ & 2023 & $28.2(0.6)$ & $1.05(0.98,1.11)$ \\
\hline Female & 7,592 & 62.3 & $27.2(27.0,27.4)$ & 2132 & $27.0(0.6)$ & ref \\
\hline \multicolumn{7}{|l|}{ Age group (years) } \\
\hline $18-29$ & 3,346 & 32.4 & $26.1(25.9,26.4)$ & 654 & $19.7(0.8)$ & ref \\
\hline $30-44$ & 5,306 & 44.6 & $28.0(27.8,28.2)$ & 1536 & $29.7(0.7)$ & $1.50(1.37,1.65)$ \\
\hline $45-64$ & 5,700 & 51.6 & $28.2(28.0,28.4)$ & 1766 & $31.2(0.7)$ & $1.58(1.45,1.73)$ \\
\hline$\geq 65$ & 769 & 5.9 & $27.7(27.3,28.0)$ & 199 & $25.3(1.8)$ & $1.28(1.09,1.51)$ \\
\hline \multicolumn{7}{|l|}{ Race/ethnicity } \\
\hline White, non-Hispanic & 8,688 & 92.4 & $27.4(27.3,27.5)$ & 2254 & $26.5(0.5)$ & ref \\
\hline Black, non-Hispanic & 2,182 & 14.2 & $29.2(28.9,29.6)$ & 834 & $37.7(1.4)$ & $1.42(1.31,1.55)$ \\
\hline Asian, non-Hispanic & 1,001 & 6.6 & $24.7(24.4,25.1)$ & 97 & $11.0(1.2)$ & $0.41(0.33,0.52)$ \\
\hline Other, non-Hispanic & 292 & 2.3 & $29.0(28.1,30.0)$ & 98 & $38.8(3.3)$ & $1.47(1.24,1.74)$ \\
\hline Hispanic & 2,958 & 19.0 & $28.3(28.1,28.5)$ & 872 & $30.5(1.0)$ & $1.15(1.07,1.24)$ \\
\hline \multicolumn{7}{|l|}{ Education } \\
\hline $\begin{array}{l}\text { Less than high school } \\
\text { diploma }\end{array}$ & 1,515 & 10.8 & $28.4(28.0,28.8)$ & 460 & $30.6(1.5)$ & $1.37(1.21,1.55)$ \\
\hline $\begin{array}{l}\text { High school or GED } \\
\text { diploma }\end{array}$ & 3,213 & 28.4 & $28.5(28.3,28.8)$ & 1050 & $33.8(1.0)$ & $1.51(1.38,1.66)$ \\
\hline Some college & 4,004 & 34.4 & $28.6(28.4,28.8)$ & 1318 & $33.1(0.9)$ & $1.48(1.36,1.62)$ \\
\hline College degree & 4,749 & 43.3 & $26.9(26.7,27.1)$ & 1035 & $22.3(0.8)$ & ref \\
\hline \multicolumn{7}{|l|}{ BY HEALTH BEHAVIORS } \\
\hline \multicolumn{7}{|l|}{ Smoking status } \\
\hline \multirow[t]{2}{*}{ Current smoker } & 2,903 & 25.9 & $27.2(27.0,27.5)$ & 724 & $25.3(1.0)$ & $0.94(0.86,1.03)$ \\
\hline & & & & & \multicolumn{2}{|c|}{ (continued on next page } \\
\hline
\end{tabular}


children achieve and maintain a healthy weight (http://www. health.gov/dietaryguidelines/Default.asp). Data on daily fruit and vegetable consumption were derived from estimates of average intake based on the frequency of eating certain types of food during the month preceding the interview. Subjects were stratified based on whether their average daily consumption of fruits and vegetables was five or more servings.

\section{Data Analysis}

Data were analyzed by survey procedures in SAS 9.3 and by SUDAAN 11 to account for the complex sample survey design. To represent the U.S. civilian, non-institutionalized population aged $\geq 18$ years, all prevalence estimates were weighted using the NHIS individual sample adult record weights. Point estimates with relative SE $>30 \%$ are noted by dashes. Proportions of obese workers stratified by various work organization factors, psychosocial factors, and I and O categories were compared to reference categories by $t$-test. Statistical significance was defined as $p \leq 0.05$. For each industry (and occupation), the reference value was set as the prevalence among all other industry (or occupation) groups. For work organization and psychosocial factors, three different models were utilized to calculate prevalence ratios (PRs) with logistic regression: an unadjusted model; one adjusted for demographic variables (Model 1); and another adjusted for demographic variables and health behaviors (Model 2). For I and O, the following three models are presented: an unadjusted model; one adjusted for demographic variables and health behaviors (Model 2); and another model adjusted for all factors included in Model 2 plus work organization/psychosocial factors significantly associated with obesity in bivariate analyses (Model 3). Data were collected in 2010 and analyzed in 2012-2013.

Data were further probed for potential interactions that would help better explore the associations between work-related factors and obesity, and whether work-related factors modify relationships between health behaviors and obesity. Specifically, we tested for two-way interactions between each of the work organization and workplace psychosocial factors significantly associated with obesity and I and $\mathrm{O}$. On the basis of associations found in previous studies, we also tested for interactions between work hours and gender and between work hours and physical activity level.

\section{Results}

\section{Prevalence of Obesity by Demographic Characteristics and Health Behaviors}

Data were available for 15,121 working adults representing approximately 135 million people. The overall prevalence of obesity among workers was $27.7 \%$. Workers aged 18-29 years, non-Hispanic Asians, and workers with college degrees had the lowest prevalence of obesity in their respective categories (Table 1).

Former smokers had a higher prevalence of obesity compared to current smokers and those who never smoked. As expected, a lower obesity prevalence was found among respondents meeting national physical activity guidelines or consuming fruits and vegetables more than five times daily (Table 1 ). 
Table 2. Prevalence of obesity and mean BMI among U.S. workers by job characteristics, 2010

\begin{tabular}{|c|c|c|c|c|c|c|c|c|}
\hline $\begin{array}{l}\text { Job } \\
\text { characteristic }\end{array}$ & $\begin{array}{l}\text { Unweighted } \\
\text { sample size }\end{array}$ & $\begin{array}{l}\text { Estimated } \\
\text { population } \\
\text { (in millions) }\end{array}$ & $\begin{array}{l}\text { Weighted mean } \\
\text { BMI }(95 \% \mathrm{Cl})\end{array}$ & $\begin{array}{l}\text { Estimated number of } \\
\text { obese workers } \\
\text { (in millions) }\end{array}$ & $\begin{array}{l}\text { Weighted } \\
\text { prevalence } \\
(\%, \mathrm{SE})\end{array}$ & $\begin{array}{c}\text { Unadjusted PR } \\
(95 \% \mathrm{Cl})\end{array}$ & $\begin{array}{l}\text { Model 1: PR } \\
(95 \% \mathrm{Cl})^{\mathrm{a}}\end{array}$ & $\begin{array}{l}\text { Model 2: PR } \\
(95 \% \mathrm{Cl})^{\mathrm{b}}\end{array}$ \\
\hline \multicolumn{9}{|c|}{ Weekly work hours } \\
\hline$<35$ & 3,517 & 31.7 & $27.0(26.8,27.2)$ & 7.9 & $24.9(0.9)$ & $0.90(0.83,0.97)$ & $0.96(0.89,1.05)$ & $0.97(0.89,1.06)$ \\
\hline $35-40$ & 7,405 & 64.2 & $27.7(27.5,27.8)$ & 17.8 & $27.7(0.6)$ & ref & ref & ref \\
\hline$>40$ & 3,924 & 36.0 & $28.0(27.8,28.3)$ & 10.8 & $30.0(0.9)$ & $1.09(1.01,1.17)$ & $1.08(1.00,1.16)$ & $1.08(1.01,1.17)$ \\
\hline \multicolumn{9}{|l|}{ Work schedule } \\
\hline Day & 10,931 & 96.9 & $27.7(27.6,27.8)$ & 27.1 & $27.9(0.5)$ & ref & ref & ref \\
\hline Other & 4,170 & 37.4 & $27.4(27.2,27.7)$ & 10.1 & $27.1(0.8)$ & $0.97(0.90,1.04)$ & $0.99(0.92,1.06)$ & $0.99(0.92,1.07)$ \\
\hline \multicolumn{9}{|l|}{ Work schedule } \\
\hline Day & 10,931 & 96.9 & $27.7(27.6,27.8)$ & 27.1 & $27.9(0.5)$ & ref & ref & ref \\
\hline Evening shift & 776 & 7.0 & $26.9(26.4,27.5)$ & 1.8 & $26.2(2.0)$ & $0.94(0.80,1.10)$ & $0.99(0.85,1.15)$ & $1.01(0.87,1.18)$ \\
\hline Night shift & 564 & 4.8 & $28.0(27.4,28.6)$ & 1.4 & $29.4(2.2)$ & $1.05(0.90,1.23)$ & $1.09(0.93,1.27)$ & $1.10(0.94,1.29)$ \\
\hline $\begin{array}{l}\text { Rotating } \\
\text { shift }\end{array}$ & 1,425 & 12.8 & $27.8(27.4,28.2)$ & 3.7 & $29.2(1.5)$ & $1.05(0.94,1.16)$ & $1.06(0.94,1.20)$ & $1.07(0.94,1.20)$ \\
\hline Other & 1,405 & 12.7 & $27.1(26.8,27.5)$ & 3.1 & 24.7 (1.3) & $0.88(0.79,0.99)$ & $0.89(0.80,1.00)$ & $0.89(0.79,0.99)$ \\
\hline \multicolumn{9}{|c|}{ Work arrangement } \\
\hline Independent & 1,531 & 13.0 & $27.1(26.8,27.5)$ & 3.3 & $25.5(1.4)$ & $0.92(0.82,1.02)$ & $0.88(0.79,0.97)$ & $0.90(0.81,1.01)$ \\
\hline On-call & 371 & 3.3 & $27.2(26.6,27.8)$ & 0.9 & $26.1(2.7)$ & $0.94(0.76,1.16)$ & $0.89(0.71,1.11)$ & $0.89(0.70,1.13)$ \\
\hline $\begin{array}{c}\text { Temporary } \\
\text { agency }\end{array}$ & 142 & 1.1 & $28.6(27.3,29.9)$ & 0.4 & 36.7 (4.8) & $1.32(1.02,1.71)$ & $1.10(0.79,1.54)$ & $1.11(0.79,1.55)$ \\
\hline $\begin{array}{r}\text { Contracting } \\
\text { company }\end{array}$ & 249 & 2.1 & $28.1(27.2,29.0)$ & 0.7 & 31.9 (3.8) & $1.15(0.91,1.45)$ & $1.14(0.90,1.46)$ & $1.09(0.86,1.38)$ \\
\hline $\begin{array}{l}\text { Regular/ } \\
\text { permanent }\end{array}$ & 12,297 & 110.1 & $27.7(27.5,27.8)$ & 30.7 & $27.8(0.5)$ & ref & ref & ref \\
\hline \multirow[t]{2}{*}{ Other } & 507 & 4.6 & $27.5(26.9,28.1)$ & 1.3 & $27.4(2.4)$ & $0.99(0.82,1.18)$ & $0.97(0.81,1.16)$ & $0.92(0.77,1.11)$ \\
\hline & & & & & & & \multicolumn{2}{|c|}{ (continued on next page) } \\
\hline
\end{tabular}




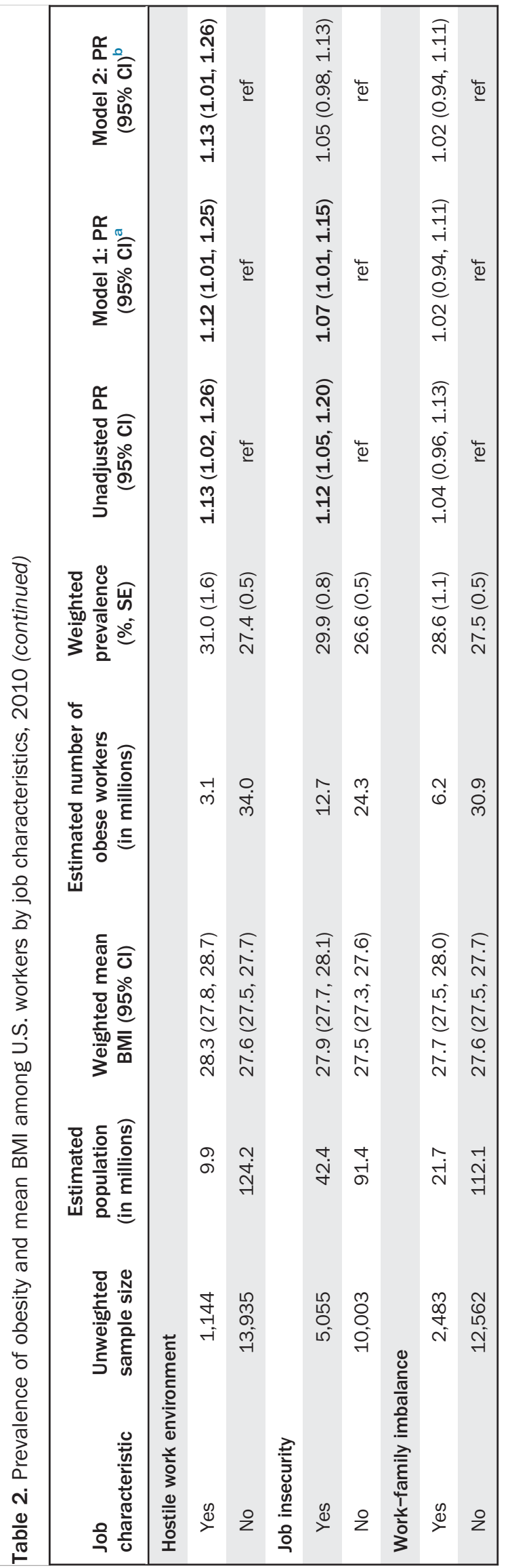

\section{Prevalence of Obesity by Work Organization and Psychosocial Factors}

Working more than 40 hours per week was significantly associated with obesity in the unadjusted model $(\mathrm{PR}=1.09,95 \% \mathrm{CI}=1.01,1.17)$, and this effect was only slightly attenuated when adjusted for demographics and health behaviors $(\mathrm{PR}=1.08, \quad 95 \% \quad \mathrm{CI}=1.01, \quad 1.17$; Table 2). Workers who reported exposure to a hostile work environment were significantly more likely to be obese according to the unadjusted model $(\mathrm{PR}=1.13$, $95 \% \mathrm{CI}=1.02,1.26$ ), and the significance of this effect persisted after adjustment for demographic characteristics and health behaviors $(\mathrm{PR}=1.13,95 \% \mathrm{CI}=1.01,1.26$; Table 2). Job insecurity was significantly associated with obesity in the unadjusted model $(\mathrm{PR}=1.12$, 95\% $\mathrm{CI}=1.05,1.20)$ and Model 1 ( $\mathrm{PR}=1.07,95 \%$ $\mathrm{CI}=1.01,1.15$ ), but adjustment for health behaviors made this effect nonsignificant. There was no significant association between obesity and work-family imbalance.

\section{Prevalence of Obesity by Industry and Occupation}

Among industry categories, public administration (PA) workers had the highest prevalence of obesity (36.3\%, $\mathrm{SE}=2.1$; Table 3). There were four industry categories with unadjusted PRs that were significantly elevated. The PRs for both manufacturing and transportation and warehousing became nonsignificant after adjustment for demographic factors (Model 1, data not shown); however, the PRs for both healthcare and social assistance (HCSA) and PA industries remained significantly elevated after adjustment for all covariates (Model 3; PR for $\mathrm{HCSA}=1.19,95 \% \mathrm{CI}=1.08,1.30$; $\mathrm{PR}$ for $\mathrm{PA}=1.26$, $95 \% \mathrm{CI}=1.12,1.43)$. On the other hand, four industry categories had unadjusted PRs that were significantly low, and the significance of three of these persisted after adjustment for all covariates.

Among occupation categories, protective service (PS) workers had the highest prevalence of obesity $(40.7 \%$, $\mathrm{SE}=3.2$, Table 4). Although eight occupational categories exhibited significantly elevated PRs in the unadjusted model, only the PRs for architecture and engineering (AE); community and social service (CS); PS; and office and administrative support (OAS) workers remained significantly elevated after adjustment for all covariates (Model 3; PR for $\mathrm{AE}=1.34,95 \% \mathrm{CI}=1.12,1.62$; $\mathrm{PR}$ for $\mathrm{CS}=1.30,95 \% \mathrm{CI}=1.06,1.60$; $\mathrm{PR}$ for $\mathrm{PS}=1.23,95 \%$ $\mathrm{CI}=1.03,1.49$; $\mathrm{PR}$ for $\mathrm{OAS}=1.12,95 \% \mathrm{CI}=1.02,1.22$ ). Six occupational categories had unadjusted PRs that were significantly low, and the significance of two of these persisted after adjustment for all covariates. 
Table 3. Prevalence of obesity and mean BMI among U.S. workers by industry (North American Industrial Classification System Sector), 2010

\begin{tabular}{|c|c|c|c|c|c|c|c|c|}
\hline Industry & $\begin{array}{l}\text { Unweighted } \\
\text { sample size }\end{array}$ & $\begin{array}{l}\text { Estimated } \\
\text { population } \\
\text { (in millions) }\end{array}$ & $\begin{array}{l}\text { Weighted mean } \\
\text { BMI }(95 \% \mathrm{Cl})\end{array}$ & $\begin{array}{l}\text { Estimated number } \\
\text { of obese workers } \\
\text { (in millions) }\end{array}$ & $\begin{array}{l}\text { Weighted } \\
\text { prevalence } \\
(\%, S E)\end{array}$ & $\begin{array}{l}\text { Unadjusted PR } \\
\qquad(95 \% \mathrm{Cl})\end{array}$ & $\begin{array}{l}\text { Model 2: PR } \\
(95 \% \mathrm{Cl})^{\mathrm{a}}\end{array}$ & $\begin{array}{l}\text { Model 3: PR } \\
(95 \% \mathrm{Cl})^{\mathrm{b}}\end{array}$ \\
\hline $\begin{array}{l}\text { Agriculture, forestry, } \\
\text { fishing, and hunting } \\
\text { (11) }\end{array}$ & 225 & 2.0 & $27.8(26.8,28.7)$ & 0.5 & $26.4(3.9)$ & $0.95(0.71,1.27)$ & 0.99 (0.73. 1.32) & $0.99(0.72,1.35)$ \\
\hline Mining (21) & 67 & 0.7 & $28.7(26.7,30.6)$ & 0.2 & $27.9(7.6)$ & $1.00(0.59,1.72)$ & $1.11(0.73,1.69)$ & $1.11(0.74,1.67)$ \\
\hline Utilities (22) & 128 & 1.3 & $28.6(27.8,29.4)$ & 0.5 & $34.1(4.8)$ & $1.23(0.93,1.62)$ & $0.92(0.65,1.32)$ & $0.88(0.61,1.29)$ \\
\hline Construction (23) & 946 & 9.1 & $28.0(27.6,28.4)$ & 2.7 & $29.8(1.6)$ & $1.08(0.96,1.20)$ & $0.99(0.88,1.12)$ & $1.01(0.90,1.14)$ \\
\hline $\begin{array}{l}\text { Manufacturing } \\
\quad(31-33)\end{array}$ & 1395 & 12.8 & $28.3(28.0,28.7)$ & 3.9 & $30.8(1.4)$ & $1.12(1.02,1.23)$ & $1.02(0.92,1.13)$ & $1.01(0.91,1.12)$ \\
\hline Wholesale trade (42) & 355 & 3.4 & $27.7(27.1,28.4)$ & 0.9 & $25.8(2.7)$ & $0.92(0.75,1.14)$ & $0.88(0.72,1.09)$ & $0.87(0.71,1.08)$ \\
\hline Retail trade (44-45) & 1527 & 14.7 & $27.5(27.1,27.8)$ & 3.8 & $25.7(1.3)$ & $0.91(0.82,1.02)$ & $0.93(0.83,1.04)$ & $0.93(0.83,1.04)$ \\
\hline $\begin{array}{l}\text { Transportation and } \\
\text { warehousing } \\
\text { (48-49) }\end{array}$ & 625 & 5.5 & $28.5(28.0,28.9)$ & 1.8 & $33.1(2.2)$ & $1.20(1.05,1.37)$ & $1.04(0.90,1.20)$ & $1.03(0.89,1.19)$ \\
\hline Information (51) & 389 & 3.4 & $28.3(27.3,29.2)$ & 1.1 & $33.1(3.0)$ & $1.19(1.00,1.42)$ & $1.16(0.96,1.39)$ & $1.15(0.95,1.38)$ \\
\hline $\begin{array}{l}\text { Finance and insurance } \\
\text { (52) }\end{array}$ & 648 & 5.8 & $27.4(26.9,28.0)$ & 1.4 & $24.4(2.1)$ & $0.87(0.74,1.03)$ & $0.94(0.80,1.10)$ & $0.94(0.81,1.10)$ \\
\hline $\begin{array}{l}\text { Real estate, rental and } \\
\text { leasing (53) }\end{array}$ & 300 & 2.5 & $26.9(26.2,27.7)$ & 0.5 & $19.9(2.8)$ & $0.71(0.54,0.94)$ & $0.69(0.52,0.91)$ & $0.68(0.51,0.90)$ \\
\hline $\begin{array}{l}\text { Professional, scientific, } \\
\text { and technical services } \\
(54)\end{array}$ & 1013 & 9.2 & $26.7(26.3,27.0)$ & 2.0 & $21.5(1.4)$ & $0.76(0.66,0.87)$ & $0.87(0.76,0.99)$ & $0.86(0.75,0.98)$ \\
\hline $\begin{array}{l}\text { Management of } \\
\text { companies and } \\
\text { enterprises (55) }\end{array}$ & 8 & 0.1 & - & - & - & - & - & - \\
\hline $\begin{array}{l}\text { Administrative, } \\
\text { support, waste } \\
\text { management, and } \\
\text { remediation services } \\
\text { (56) }\end{array}$ & 717 & 5.9 & $27.9(27.4,28.4)$ & 1.7 & $29.0(1.9)$ & $1.04(0.91,1.19)$ & $0.99(0.85,1.16)$ & $1.01(0.87,1.18)$ \\
\hline Education services (61) & 1462 & 13.2 & $27.2(26.8,27.5)$ & 3.5 & $26.1(1.4)$ & $0.93(0.83,1.04)$ & $1.06(0.95,1.19)$ & $1.07(0.96,1.20)$ \\
\hline $\begin{array}{l}\text { Healthcare and social } \\
\text { assistance (62) }\end{array}$ & 2136 & 17.8 & $28.1(27.7,28.4)$ & 5.7 & $32.0(1.3)$ & $1.18(1.08,1.28)$ & $1.18(1.08,1.30)$ & $1.19(1.08,1.30)$ \\
\hline \multicolumn{9}{|c|}{ (continued on next page) } \\
\hline
\end{tabular}




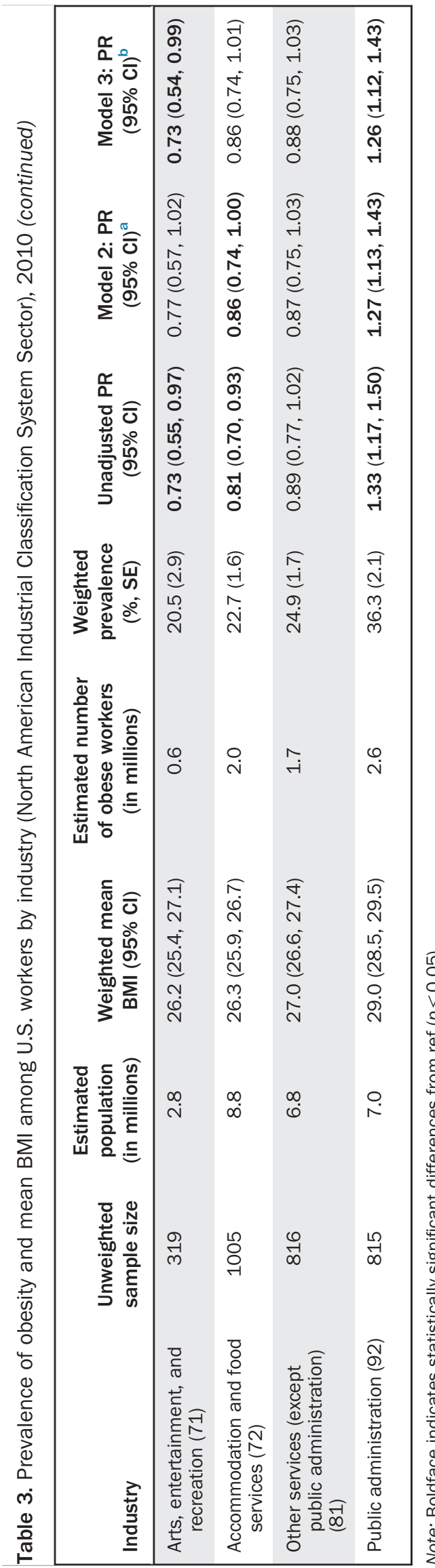

We found no statistically significant interactions between work hours and I and $\mathrm{O}$, gender, or physical activity, or between hostile work environment and I and O.

\section{Discussion}

This study found significant, albeit modest, associations between long work hours, hostile work environments, and obesity among a nationally representative sample inclusive of U.S. workers from all I and $\mathrm{O}$ categories. These associations persisted after adjustment for demographic characteristics and health behaviors. There were also a few I and $\mathrm{O}$ categories that were associated with increased prevalence of obesity, even after adjustment for demographic characteristics, health behaviors, long work hours, and hostile work environment. These findings suggest that there may be other work-related variables not included in this study (e.g., occupational physical activity or occupational sedentariness) that vary by I and $\mathrm{O}$ and contribute to obesity.

The finding regarding long work hours is consistent with a previous longitudinal study in which men (but not women) had increased odds of having excess body weight if they worked long hours at baseline, and men who changed from standard to long hours over the course of the study had increased odds of experiencing an unhealthy weight gain compared with men who continued to work standard hours. ${ }^{7}$ Similarly, Ostry et al. ${ }^{13}$ found elevated BMIs among men working 35 or more hours per week, even after controlling for job strain. Unlike previous studies, the current study included analyses that controlled for health behaviors, and found that the association between long work hours and obesity persisted.

This study also found an association between exposure to a hostile work environment and obesity, which persisted after adjustment for demographic and health behavior variables. It may be that hostile work environments, like other stressors, promote obesity through an increase in total caloric intake, ${ }^{16,38}$ which is unexplained by fruit and vegetable consumption. Alternatively, as the present study is cross-sectional, a reverse association cannot be ruled out. That is, workers who are already obese may be more likely to experience harassment or bullying on the job. Longitudinal studies of workplace and hostility may help clarify this relationship.

After adjustment, there was an association between obesity and employment in HCSA industries. The occupational categories of CS and healthcare support were also positively associated with obesity, but the category of healthcare practitioners and technical occupations was not. This finding is consistent with a previous study based on NHIS data from 1986 through 
Table 4. Prevalence of obesity and mean BMI among U.S. workers by occupation (Standard Occupational Classification Major Group), 2010

\begin{tabular}{|c|c|c|c|c|c|c|c|c|}
\hline Occupation & $\begin{array}{l}\text { Unweighted } \\
\text { sample size }\end{array}$ & $\begin{array}{l}\text { Estimated } \\
\text { population (in } \\
\text { millions) }\end{array}$ & $\begin{array}{l}\text { Weighted mean } \\
\text { BMI }(95 \% \mathrm{Cl})\end{array}$ & $\begin{array}{c}\text { Estimated } \\
\text { number of } \\
\text { obese workers } \\
\text { (in millions) }\end{array}$ & $\begin{array}{l}\text { Weighted } \\
\text { prevalence } \\
(\%, S E)\end{array}$ & $\begin{array}{l}\text { Unadjusted PR } \\
\quad(95 \% \mathrm{Cl})\end{array}$ & $\begin{array}{l}\text { Model 2: PR } \\
(95 \% \mathrm{Cl})^{\mathrm{a}}\end{array}$ & $\begin{array}{l}\text { Model 3: PR } \\
(95 \% \mathrm{Cl})^{\mathrm{b}}\end{array}$ \\
\hline Management (11) & 1352 & 13.1 & $28.1(27.7,28.4)$ & 3.7 & $28.2(1.4)$ & $1.01(0.91,1.13)$ & $1.08(0.96,1.20)$ & $1.06(0.94,1.19)$ \\
\hline $\begin{array}{l}\text { Business and financial } \\
\text { operations (13) }\end{array}$ & 718 & 6.2 & $27.3(26.8,27.8)$ & 1.5 & $24.9(1.9)$ & $0.89(0.77,1.04)$ & $1.02(0.88,1.17)$ & $1.02(0.89,1.17)$ \\
\hline $\begin{array}{l}\text { Computer and } \\
\text { mathematical (15) }\end{array}$ & 431 & 3.9 & $27.3(26.6,28.0)$ & 1.0 & $25.7(2.6)$ & $0.92(0.75,1.12)$ & $1.00(0.82,1.22)$ & $1.01(0.83,1.22)$ \\
\hline $\begin{array}{l}\text { Architecture and } \\
\text { engineering (17) }\end{array}$ & 276 & 2.7 & $28.0(27.3,28.7)$ & 0.9 & $34.1(3.4)$ & $1.23(1.01,1.49)$ & $1.36(1.13,1.63)$ & $1.34(1.12,1.62)$ \\
\hline $\begin{array}{l}\text { Life, physical, and } \\
\text { social science (19) }\end{array}$ & 167 & 1.6 & $25.7(24.9,26.5)$ & 0.2 & $14.2(2.9)$ & $0.51(0.34,0.76)$ & $0.73(0.51,1.06)$ & $0.74(0.51,1.07)$ \\
\hline $\begin{array}{l}\text { Community and social } \\
\text { service (21) }\end{array}$ & 296 & 2.5 & $28.2(27.5,29.0)$ & 0.9 & $35.6(3.7)$ & $1.28(1.05,1.57)$ & $1.30(1.06,1.58)$ & $1.30(1.06,1.60)$ \\
\hline Legal (23) & 178 & 1.7 & $27.3(26.3,28.2)$ & 0.4 & $23.3(3.9)$ & $0.83(0.60,1.16)$ & $0.85(0.62,1.15)$ & $0.80(0.58,1.10)$ \\
\hline $\begin{array}{l}\text { Education, training, } \\
\text { and library (25) }\end{array}$ & 956 & 8.8 & $27.1(26.6,27.5)$ & 2.2 & $24.7(1.7)$ & $0.88(0.76,1.02)$ & $1.06(0.92,1.22)$ & $1.07(0.93,1.23)$ \\
\hline $\begin{array}{l}\text { Art, design, } \\
\text { entertainment, } \\
\text { sports, and media } \\
\text { (27) }\end{array}$ & 325 & 2.8 & $26.0(25.2,26.8)$ & 0.6 & $20.1(2.8)$ & $0.72(0.55,0.94)$ & $0.80(0.61,1.03)$ & $0.77(0.59,1.01)$ \\
\hline $\begin{array}{l}\text { Healthcare } \\
\text { practitioners and } \\
\text { technical (29) }\end{array}$ & 771 & 6.6 & $26.5(26.0,26.9)$ & 1.4 & $22.0(1.7)$ & $0.78(0.67,0.91)$ & $0.88(0.76,1.03)$ & $0.89(0.76,1.03)$ \\
\hline $\begin{array}{l}\text { Healthcare support } \\
\text { (31) }\end{array}$ & 411 & 3.3 & $28.7(27.8,29.7)$ & 1.1 & $34.8(3.0)$ & $1.26(1.06,1.49)$ & $1.16(0.96,1.40)$ & $1.15(0.94,1.40)$ \\
\hline Protective service (33) & 321 & 2.7 & $29.8(29.2,30.5)$ & 1.1 & $40.7(3.2)$ & $1.48(1.26,1.73)$ & $1.24(1.04,1.49)$ & $1.23(1.03,1.49)$ \\
\hline $\begin{array}{l}\text { Food preparation and } \\
\text { serving related (35) }\end{array}$ & 824 & 7.3 & $26.3(25.8,26.8)$ & 1.7 & 23.1 (1.8) & $0.82(0.70,0.96)$ & $0.85(0.72,1.01)$ & $0.86(0.72,1.02)$ \\
\hline $\begin{array}{l}\text { Building and ground } \\
\text { cleaning and } \\
\text { maintenance (37) }\end{array}$ & 660 & 5.2 & $27.0(26.5,27.4)$ & 1.2 & $23.5(2.0)$ & $0.84(0.71,0.99)$ & $0.74(0.61,0.90)$ & $0.76(0.62,0.92)$ \\
\hline \multicolumn{9}{|r|}{ tinued on next page) } \\
\hline
\end{tabular}


Table 4. Prevalence of obesity and mean BMI among U.S. workers by occupation (Standard Occupational Classification Major Group), 2010 (continued)

\begin{tabular}{|c|c|c|c|c|c|c|c|c|}
\hline Occupation & $\begin{array}{l}\text { Unweighted } \\
\text { sample size }\end{array}$ & $\begin{array}{l}\text { Estimated } \\
\text { population (in } \\
\text { millions) }\end{array}$ & $\begin{array}{l}\text { Weighted mean } \\
\text { BMI }(95 \% \mathrm{Cl})\end{array}$ & $\begin{array}{c}\text { Estimated } \\
\text { number of } \\
\text { obese workers } \\
\text { (in millions) }\end{array}$ & $\begin{array}{l}\text { Weighted } \\
\text { prevalence } \\
(\%, \mathrm{SE})\end{array}$ & $\begin{array}{l}\text { Unadjusted PR } \\
\qquad(95 \% \mathrm{Cl})\end{array}$ & $\begin{array}{l}\text { Model 2: PR } \\
(95 \% \mathrm{Cl})^{\mathrm{a}}\end{array}$ & $\begin{array}{l}\text { Model 3: PR } \\
(95 \% \mathrm{Cl})^{\mathrm{b}}\end{array}$ \\
\hline $\begin{array}{l}\text { Personal care and } \\
\text { service (39) }\end{array}$ & 581 & 4.9 & $28.1(27.4,28.8)$ & 1.6 & $32.7(2.4)$ & $1.18(1.02,1.37)$ & $1.14(0.97,1.34)$ & $1.16(0.98,1.37)$ \\
\hline Sales and related (41) & 1489 & 13.9 & $27.2(26.9,27.5)$ & 3.4 & $24.4(1.3)$ & $0.86(0.77,0.97)$ & $0.87(0.77,0.98)$ & $0.86(0.76,0.97)$ \\
\hline $\begin{array}{l}\text { Office and } \\
\text { administrative } \\
\text { support (43) }\end{array}$ & 2011 & 17.3 & $27.9(27.6,28.3)$ & 5.3 & 30.7 (1.2) & $1.12(1.03,1.22)$ & $1.11(1.01,1.21)$ & $1.12(1.02,1.22)$ \\
\hline $\begin{array}{l}\text { Farming, fishing, and } \\
\text { forestry (45) }\end{array}$ & 106 & 0.9 & $27.5(26.3,28.8)$ & 0.2 & $27.5(4.5)$ & $0.99(0.71,1.37)$ & $1.01(0.73,1.40)$ & $0.97(0.69,1.37)$ \\
\hline $\begin{array}{r}\text { Construction and } \\
\text { extraction (47) }\end{array}$ & 753 & 7.3 & $27.9(27.5,28.3)$ & 2.0 & 27.5 (1.9) & $0.99(0.86,1.13)$ & $0.88(0.76,1.03)$ & $0.89(0.76,1.04)$ \\
\hline $\begin{array}{l}\text { Installation, } \\
\text { maintenance, and } \\
\text { repair (49) }\end{array}$ & 508 & 4.8 & $28.2(27.6,28.7)$ & 1.4 & $29.6(2.5)$ & $1.07(0.90,1.26)$ & $0.92(0.77,1.10)$ & $0.92(0.76,1.10)$ \\
\hline Production (51) & 896 & 7.8 & $28.6(28.1,29.1)$ & 2.5 & 32.1 (1.9) & $1.17(1.03,1.32)$ & $0.98(0.85,1.13)$ & $0.98(0.85,1.13)$ \\
\hline $\begin{array}{l}\text { Transportation and } \\
\text { material moving (53) }\end{array}$ & 851 & 7.7 & $28.5(28.0,29.1)$ & 2.5 & $32.8(1.9)$ & $1.19(1.05,1.35)$ & $1.06(0.92,1.22)$ & $1.06(0.92,1.22)$ \\
\hline
\end{tabular}

Note: Boldface indicates statistically significant differences from ref $(p \leq 0.05)$.

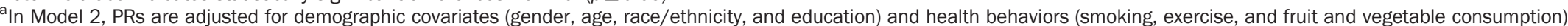

${ }^{b}$ In Model 3, PRs are adjusted for demographic covariates; health behaviors (smoking, exercise, and fruit and vegetable consumption); long work hours; and hostile work environment

PR, prevalence ratio 
2002, which reported that female health services were among the occupational categories with the highest pooled obesity rates, while both male and female workers in health-diagnosing occupations, which generally have higher incomes, exhibited some of the lowest obesity rates. ${ }^{21}$ These conflicting findings support observations from a recent qualitative, participatory investigation suggesting that the impact of working conditions on obesity may be especially harmful for lower-income workers. ${ }^{39}$

The only other industry category significantly associated with obesity in the present study after controlling for all covariates was PA. Similar to the earlier NHIS study, the present study also found a high prevalence of obesity among workers in the PS occupations, many of whom are employed in PA industries. The other occupational categories significantly associated with obesity in this study after controlling for all covariates were OAS support and AE. The finding of increased obesity among the latter group was surprising given that the previous NHIS study found very low prevalence rates of obesity among female architects and surveyors. ${ }^{21}$ More in-depth studies of workers within these groups are needed to elucidate the specific factors contributing to their increased obesity prevalence. Consistent with a recent Gallup study, ${ }^{40}$ the present study found high unadjusted PRs for obesity among transportation and material moving occupations and production occupations, but these results were no longer significant after adjustment.

Associations between work organization and psychosocial workplace exposure variables captured by the 2010 NHIS-OHS and I and $\mathrm{O}$ have been described previously. ${ }^{35,36}$ The fact that most of the differences in the prevalence of obesity among I and $\mathrm{O}$ groups persisted after adjustment for the subset of work organization and workplace psychosocial factors significantly associated with obesity suggests that I and $\mathrm{O}$ differences in obesity prevalence may be related, at least partially, to occupational factors that were not captured in this study (e.g., income, job strain, and/or aerobic occupational physical activity).

\section{Strengths and Limitations}

The main strengths of this study are (1) that it is based on a large, nationally representative sample that includes U.S. workers from all I and O categories and (2) that the 2010 NHIS includes data on many demographic variables, health behaviors, and supplemental occupational variables useful for multivariable analyses. Some of the main limitations are that all data are self-reported and cross-sectional. In particular, BMI calculations based on self-reported height and weight values are subject to error, as they tend to underestimate obesity prevalence. $^{41,42}$ In addition, as described by Alterman et al., ${ }^{36}$ single questions were used to measure complex constructs such as exposure to a hostile work environment and job insecurity because more detailed information on these factors was beyond the scope of the NHIS. There are also limitations associated with the measures used to assess health behaviors, which were based on published guidelines. In particular, the low prevalence of meeting fruit and vegetable consumption recommendations limited the utility of this variable.

The economic climate and high unemployment rates in the U.S. in 2010 should also be considered when interpreting our findings, as these conditions could have influenced the NHIS-OHS estimates. Finally, this is an exploratory study that involves many comparisons. Significance was defined as $p<0.05$ to provide a high level of sensitivity for meaningful associations, but some of the significant findings may be due to chance.

\section{Conclusions}

In summary, this study presents additional evidence that selected occupational factors, specifically long work hours, hostile work environments, and employment in certain industries and occupations, may contribute to the current epidemic of obesity in the U.S. Public health professionals and employers should consider workplace interventions aimed at reducing obesity that take organization-level factors, such as scheduling and prevention of workplace hostility, into account along with individual-level health behaviors such as diet and exercise. This could be done as part of the Total Worker Health $^{\mathrm{TM}}$ approach advocated by NIOSH, which involves integration of occupational safety and health protection with health promotion to prevent worker injury and illness and to advance health and well-being (see http:// www.cdc.gov/niosh/TWH/).

The authors express their appreciation to the many other persons, both within and outside of NIOSH and NCHS, who contributed to study planning, questionnaire development, and/or review of previous drafts of this paper. These include, but are not limited to, Marie Haring Sweeney, Toni Alterman, John Sestito, Aaron Sussell, Jim Dahlhamer, Brian Ward, Aleck Ostry, and Alberto Cabán-Martinez.

No financial disclosures were reported by the authors of this paper. The findings and conclusions in this report are those of the authors and do not necessarily represent the views of NIOSH. 


\section{References}

1. CDC. Vitalsigns: adult obesity. http://www.cdc.gov/VitalSigns/pdf/ 2010-08-vitalsigns.pdf.

2. Ogden CL, Carroll MD, Kit BK, Flegal KM. Prevalence of obesity in the U.S., 2009-2010. NCHS Data Brief 2012;No. 82.

3. Goetzel RZ, Pei X, Tabrizi MJ, et al. Ten modifiable health risk factors are linked to more than one-fifth of employer-employee health care spending. Health Aff 2012;31(11):2474-84.

4. Schulte PA, Wagner GR, Ostry A, et al. Work, obesity, and occupational safety and health. Am J Public Health 2007;97(3):428-36.

5. Pandalai SP, Schulte PA, Miller DB. Conceptual heuristic models of the interrelationships between obesity and the occupational environment. Scand J Work Environ Health 2013;39(3):221-32.

6. Solovieva S, Lallukka T, Virtanen M, Viikari-Juntura E. Psychosocial factors at work, long work hours, and obesity: a systematic review. Scand J Work Environ Health 2013;39(3):241-58.

7. Shields M. Long working hours and health. Health Rep 1999;11(2): 33-48.

8. van Amelsvoort LGPM, Schouten EG, Kok FJ. Duration of shiftwork related to body mass index and waist to hip ratio. Int J Obes 1999;23(9): 973-8.

9. Di Lorenzo L, De Pergola G, Zocchetti C, et al. Effect of shift work on body mass index: results of a study performed in 319 glucose-tolerant men working in a Southern Italian industry. Int J Obes 2003;27(11):1353-8.

10. Morikawa $Y$, Nakagawa H, Miura K, et al. Effect of shift work on body mass index and metabolic parameters. Scand J Work Environ Health 2007;33(1):45-50.

11. Zhao I, Bogossian F, Turner C. A cross-sectional analysis of the association between night-only or rotating shift work and overweight/ obesity among female nurses and midwives. J Occup Environ Med 2012;54(7):834-40

12. Zhao I, Bogossian F, Turner C. Does maintaining or changing shift types affect BMI? A longitudinal study. J Occup Environ Med 2012;54 (5):525-31.

13. Ostry AS, Radi S, Louie AM, LaMontagne AD. Psychosocial and other working conditions in relation to body mass index in a representative sample of Australian workers. BMC Public Health 2006;6:53.

14. Wardle J, Steptoe A, Oliver G, Lipsey Z. Stress, dietary restraint and food intake. J Psychosom Res 2000;48(2):195-202.

15. O'Connor DB, Jones F, Conner M, McMillan B. Effects of daily hassles and eating style on eating behavior. Health Psychol 2008;27(1S):S20-S31.

16. Groesz LM, McCoy S, Carl J, et al. What is eating you? Stress and the drive to eat. Appetite 2012;58(2):717-21.

17. Barrington WE, Ceballos RM, Bishop SK, McGregor BA, Beresford SAA. Perceived stress, behavior, and body mass index among adults participating in a worksite obesity prevention program, Seattle, 20052007. Prev Chronic Dis 2012;9:E152.

18. Jones F, O'Connor DB, Conner M, McMillan B. Impact of daily mood, work hours, and iso-strain variables on self-reported health behaviors. J Appl Psychol 2007;92(6):1731-40.

19. Antunes LC, Levandovski R, Dantas G, Caumo W, Hidalgo MP. Obesity and shift work: chronobiological aspects. Nutr Res Rev 2010;23 (1):155-68.

20. Speaker KJ, Fleshner M. Interleukin-1 beta: a potential link between stress and the development of visceral obesity. BMC Physiol 2012;2:8.

21. Caban AJ, Lee DJ, Fleming LE, Gómez-Marín O, LeBlanc W, Pitman T. Obesity in U.S. workers: the National Health Interview Survey, 1986 to 2002. Am J Public Health 2005;95(9):1614-22.

22. NIOSH. Stress... at work. Cincinnati OH: U.S. Department of Health and Human Services, CDC, National Institute for Occupational Safety and Health, DHHS (NIOSH), 1999, Publication No. 99-101.
23. Karasek RA. Job demands, job decision latitude, and mental strain: implications for job redesign. Adm Sci Q 1979;24:285-308.

24. Hellerstedt WL, Jeffery RW. The association of job strain and health behaviours in men and women. Int J Epidemiol 1997;26(3):575-83.

25. Nyberg ST, Heikkilä K, Fransson EI, et al. Job strain in relation to body mass index: pooled analysis of 160000 adults from 13 cohort studies. J Intern Med 2012;272(1):65-73.

26. Kivimäki M, Leino-Arjas $P$, Luukonen R, Riihimäki H, Vahtera J, Kirjonen J. Work stress and risk of cardiovascular mortality: prospective cohort study of industrial employees. BMJ 2002;325(7369):857-61.

27. Kuovonen A, Kivimäki M, Cox SJ, Cox T, Vahtera J. Relationship between work stress and body mass index among 45,810 female and male employees. Psychosom Med 2005;67(4):577-83.

28. Siegrist J. Adverse health effects of high-effort/low-reward conditions. J Occup Health Psychol 1996;1(1):27-41.

29. Hansen ÅM, Hogh A, Persson R, Karlson B, Garde AH, Ørbæk P. Bullying at work, health outcomes, and physiological stress response. J Psychosom Res 2006;60(1):63-72.

30. Hogh A, Hansen ÅM, Mikkelsen EG, Persson R. Exposure to negative acts at work, psychological stress reactions and physiological stress response. J Psychosom Res 2012;73(1):47-52.

31. Ferrie J, Shipley M, Stansfeld S, Marmot M. Effects of chronic job insecurity and change in job security on self-reported health, minor psychiatric morbidity, physiological measures, and health related behaviours in British civil servants: the Whitehall II Study. J Epidemiol Community Health 2002;56(6):450-4.

32. Muenster E, Rueger H, Ochsmann E, Letzel S, Toschke AM. Association between overweight, obesity and self-perceived job insecurity in German employees. BMC Public Health 2011;11:162-9.

33. Landsbergis PA, Grzywacz JG, LaMontagne AD. Work organization, job insecurity, and occupational health disparities. Am J Ind Med 2012(In press).

34. Moen P, Kelly EL, Tranby E, Huang Q. Changing work, changing health: can real work-time flexibility promote health behaviors and well-being? J Health Soc Behav 2011;52(4):404-29.

35. Alterman T, Luckhaupt SE, Dahlhamer JM, Ward BW, Calvert GM. Prevalence rates of work organization characteristics among workers in the U.S: data from the 2010 National Health Interview Survey. Am J Ind Med 2013;56(6):647-59.

36. Alterman T, Luckhaupt SE, Dahlhamer JM, Ward BW, Calvert GM. Job insecurity, work-family imbalance, and hostile work environment: prevalence data from the 2010 National Health Interview Survey. Am J Ind Med 2013;56(6):660-9.

37. National Center for Health Statistics. 2010 National Health Interview Survey (NHIS) Public Use Data Release. NHIS survey description 2011.

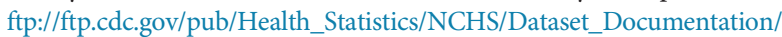
NHIS/2010/srvydesc.pdf.

38. Epel E, Lapidus R, McEwen B, Brownell K. Stress may add bite to appetite in women: a laboratory study of stress-induced cortisol and eating behavior. Psychoneuroendocrinology 2001;26(1):37-49.

39. Champagne N, Abreu M, Nobrega S, et al. Obesity/overweight and the role of working conditions: a qualitative, participatory investigation, 2012. http://drupal.masscosh.org/files/Obesity\%20and\%20Work \%20Report,\%20Embargoed\%20until\%2011-13.pdf.

40. Gallup, Inc. For U.S. workers, lack of exercise most linked to obesity, 2013. http://www.gallup.com/poll/162359/workers-lack-exercise-linkedobesity.aspx.

41. Nyholm M, Gullberg B, Merlo J, Lundqvist-Persson C, Råstam L, Lindblad U. The validity of obesity based on self-reported weight and height: implications for population studies. Obesity 2007;15(1):197-208.

42. Stommel M, Schoenborn CA. Accuracy and usefulness of BMI measures based on self-reported weight and height: findings from the NHANES \& NHIS 2001-2006. BMC Public Health 2009;9:421. 